\title{
Edukasi Stop Merokok di dalam Rumah di Dusun Krandon, Kwaren, Kecamatan Ngawen, Kabupaten Klaten

\author{
Fardhiasih Dwi Astuti ${ }^{1}$, Aulia Putri Nugraheni ${ }^{2}$ \\ ${ }^{1,2}$ Fakultas Kesehatan Masyarakat, Universitas Ahmad Dahlan Yogyakarta \\ E-mail: ${ }^{1}$ fardhiasih.dwiastuti@ikm.uad.ac.id, ${ }^{2}$ aulia1800029240@webmail.uad.ac.id
}

\begin{abstract}
Abstrak
Perilaku merokok menjadi salah satu permasalahan kesehatan yang serius. Indonesia menduduki peringkat ketiga dengan jumlah perokok terbanyak di dunia. Berdasarkan data riskesdas 2018 persentase perokok diatas 15 tahun sebanyak 33,8\%. Hasil survey Perilaku Hidup Bersih dan Sehat (PHBS) di Dusun Krandon, Kwaren, Ngawen, Klaten, khususnya indikator tidak merokok di dalam rumah pada masyarakat RT 02 diperoleh sebesar $57 \%$ responden yang merokok di dalam rumah. Persentase ini menunjukkan bahwa kesadaran untuk tidak merokok di dalam rumah masih rendah. Pegabdian ini bertujuan melakukan edukasi stop merokok didalam rumah. Metode yang digunakan dalam penngabdian ini adalah eduksi dengan penyuluhan dan pemasangan poster yang dilanjutkan dengan evaluasi. Berdasarkan kegiatan yang telah dilakukan didapatkan hasil bahwa masyarakat antusias dalam kegiatan. Hasil evaluasi masyarakat merasa kegiatan sangat bermanfaat dan dapat meningkatkan pengetahuan tentang bahaya merokok. Peggunaan poster dapat mengingtkan masyarakat untuk tidak merokok didalam rumah. Kegiatan ini merupakan salah satu upaya mengedukasi masyarakat tentang bahaya merokok dan menjadikan masyarakat berperilaku lebih baik dengan berhenti merokok. Kegiatan edukasi perlu ditingkatkan agar masyarakat lebih sehat.
\end{abstract}

Kata kunci: rokok, penyuluhan, poster

\begin{abstract}
Smoking behavior is a serious health problem. Indonesia ranks third with the highest number of smokers in the world. Based on the 2018 Riskesdas data, the percentage of smokers over 15 years is 33.8\%. The Clean and Healthy Life Behavior (PHBS) survey in Krandon Kwaren, Ngawen, Klaten, the indicator of not smoking in the house in the RT 02 community, obtained $57 \%$ of respondents who smoked in the house. This percentage shows that awareness not to smoke in the house is still low. This service aims to provide education to stop smoking in the home. The method used in this service is education with counseling and poster installation followed by evaluation. Based on the activities that have been carried out, it was found that the community was enthusiastic about the activities. The results of the community evaluation felt that the activity was beneficial and could increase knowledge about the dangers of smoking. The use of posters can remind people not to smoke in the house. This activity is an effort to educate the public about the dangers of smoking and make people behave better by quitting smoking. Educational activities need to be improved so that the community is healthier.
\end{abstract}

Keywords: cigarettes, counseling, poster

\section{PENDAHULUAN}

Perilaku merokok menjadi salah satu permasalahan kesehatan yang serius, melihat dari dampak atau bahaya yang akan diakibatkan dari perilaku tersebut. Merokok dapat menyebabkan beberapa penyakit serius dan berbahaya seperti penyakit paru-paru, kanker, penyakit impotensi 
dan reproduksi, penyakit lambung, serta penyakit stroke. Pada perokok pasif, asap rokok dapat menyebabkan beberapa penyakit serius, seperti penyakit kardiovaskuler dan pernafasan yang serius, penyakit jantung koroner (PJK) serta kanker paru-paru [1]

Indonesia menjadi salah satu negara dengan jumlah perokok aktif tertinggi dibanding negara negara yang melaksanakan Global Adult Tobacco Survey (GATS) 16 low dan middle income countries [2]. Indonesia menduduki peringkat ketiga dengan jumlah perokok terbanyak di dunia setelah China dan India [3].

Prevalensi perilaku merokok di Indonesia tergolong cukup tinggi. Berdasarkan data riskesdas 2018 persentase perokok diatas 15 tahun sebanyak 33,8\%. Persentase jumlah keseluruhan perokok laki-laki sebesar $62,9 \%$ sedangkan persentase jumlah keseluruhan perokok perempuan sebesar 4,8\%. Hal ini membuktikan bahwa jumlah perokok terbanyak adalah laki-laki [4]

Perokok pasif adalah orang yang menghirup asap rokok dari perokok aktif dan sukarela menghisap asap rokok sebagai konsekuensi karena berada di lingkungan. Hal ini berarti semakin banyak pengguna rokok di suatu negara maka semakin tinggi pula jumlah perokok pasif atau penghirup asap rokok di negara tersebut. Perokok pasif merupakan orang yang paling menderita, karena harus menerima dampak dari paparan asap rokok orang lain [5].

Indonesia menempati urutan pertama untuk persentase jumlah perokok pasif menurut pada Global Adults Tobacco Survey (GATS) tahun 2011 yaitu sebesar 78,4\%. Keterpaparan asap rokok di Indonesia pada tahun 2015 sebanyak 113 juta atau sebesar 78\% orang terpapar asap rokok dirumah. Di Indonesia, keterpaparan asap rokok dirumah menempati urutan pertama dan paling tinggi diantara negara lain [6]. Presentase merokok di dalam rumah di provinsi Jawa Tengah sebesar 83,8\% lebih tinggi dari DKI Jakarta, Jawa Barat, Jawa Timur [7].

Hasil survey Perilaku Hidup Bersih dan Sehat (PHBS) di Dusun Krandon, Kwaren, Ngawen, Klaten, khususnya indikator tidak merokok di dalam rumah pada masyarakat RT 02 diperoleh sebesar $57 \%$ responden yang merokok di dalam rumah. Persentase ini menunjukkan bahwa kesadaran untuk tidak merokok di dalam rumah masih rendah. Hasil ini diperkuat dengan pendapat dari ketua RT 02 dan kader kesehatan yang aktif di Dusun Krandon, bahwa masih banyaknya masyarakat yang memiliki kebiasaan merokok di dalam rumah dan masalah ini perlu untuk segera di lakukan intervensi.

Hasil survei yang dilakukan pada masyarakat RT 02 Dusun Krandon tahun 2021 menyebutkan bahwa kebiasaan merokok di dalam rumah menjadi prioritas masalah utama. Sehingga perlu dilakukan intervensi pada permasalahan tersebut. Salah satu upaya yang dapat dilakukan untuk mengatasi kebiasaan merokok di dalam rumah adalah dengan memberikan edukasi tentang bahaya dan dampak merokok di dalam rumah.

Ilustrasi tersebut yang melatar belakangi penulis untuk melakukan upaya edukasi dengan penyuluhan stop merokok di dalam rumah dengan metode presentasi sekaligus pemutaran video bahaya dan dampak merokok di dalam rumah serta dengan pemasangan poster. Pengabdian edukasi stop merokok dengan menggunakan media tersebut, dapat meningkatkan kesadaran dan pengetahuan masyarakat Dusun Krandon untuk tidak merokok di dalam rumah.

\section{METODE}

Metode yang digunakan pada pengabdian edukasi stop merokok didalam rumah ini menggunakan beberapa tahap. Tahap pertama dengan metode penyuluhan dengan presentasi menggunakan power point disertai dengan pemutaran video. Tahap kedua yaitu dengan pemasangan poster Rumah Bebas Asap Rokok. Tahap ketiga adalah evaluasi pelaksanaan kegiatan.

\subsection{Penyuluhan}

Edukasi stop merokok di dalam rumah dilakukan dengan penyuluhan menggunakan power point disertai dengan pemutaran video. Materi penyuluhan berupa kandungan rokok dan bahanyanya bagi tubuh manusia. Dampak rokok pada perokok aktif dan pasif dan bahayanya langsung merokok setelah berbuka puasa. Video dalam kegiatan ini digunakan untuk 
menguatkan dampak pengaruh rokok terhadap tubuh manusia.

\subsection{Poster Rumah Bebas Asap Rokok}

Poster ditempelkan di tempat umum dimana masyarakat dapat melihat dan mengingatkan agar tidak merokok didalam rumah. Poster ditempelkan Poster pada area Masjid yang digunakan sebagai tempat ibadah sebagian besar warga di Dusun Krandon. Dengan pemasangan poster ini diharapkan warga terus teringat agar tidak merokok didalam rumah. Poster yang ditempel seperti pada Gambar 1.

\subsection{Evaluasi Pelaksanaan}

Evaluasi dilakukan untuk penilaian kemanfaatan dari penyuluhan yang dilakukan. Penilaian evaluasi terkait dari materi, cara penyampaian dan pemahaman materi yang disampaikan.

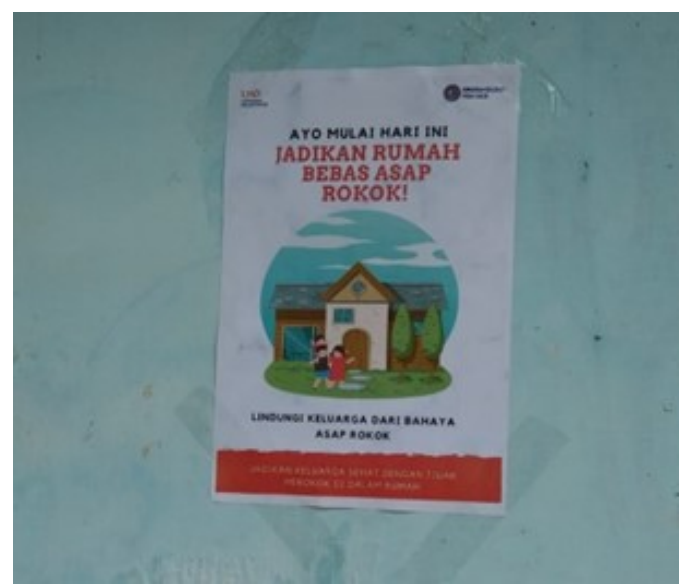

Gambar 1. Poster Rumah Bebas Asap Rokok.

\section{HASIL DAN PEMBAHASAN}

Kegiatan Edukasi Stop merokok di dalam rumah dilakukan di Dusun Krandon. Jumlah peserta yang hadir sebanyak 88 orang yang berasal dari seluruh RT di Dusun Krandon. Penyuluhan di awali dengan sambutan oleh ketua RT 02 lalu dilanjutkan dengan presentasi tentang stop merokok di dalam rumah. Materi yang disampaikan pada edukasi stop merokok dalam rumah berupa tentang kandungan rokok, bahaya dan dampak dari rokok untuk kesehatan bagi perokok aktif maupun pasif, serta bahaya langsung merokok setelah berbuka puasa. Pemaparan materi disertai dengan pemutaran video testimoni penderita penyakit akibat merokok.

Selama pemaparan materi, masyarakat aktif dalam merespon pertanyaan yang diajukan oleh pemateri sehingga membuat penyuluhan semakin hidup dan menarik. Edukasi stop merokok saat penyuluhan juga diberikan motivasi kepada masyarakat untuk mengurangi merokok serta menghimbau untuk tidak merokok di dalam rumah. Masyarakat terlihat antusias dan cukup aktif merespon dalam kegiatan penyuluhan tersebut. Masyarakat dapat melihat dan merasakan secara langsung dampak dari merokok di dalam rumah dengan melihat ilustrasi video yang ditampilkan saat penyuluhan. Pelaksanaan kegiatan penyuluhan dapat diihat pada Gambar 2 


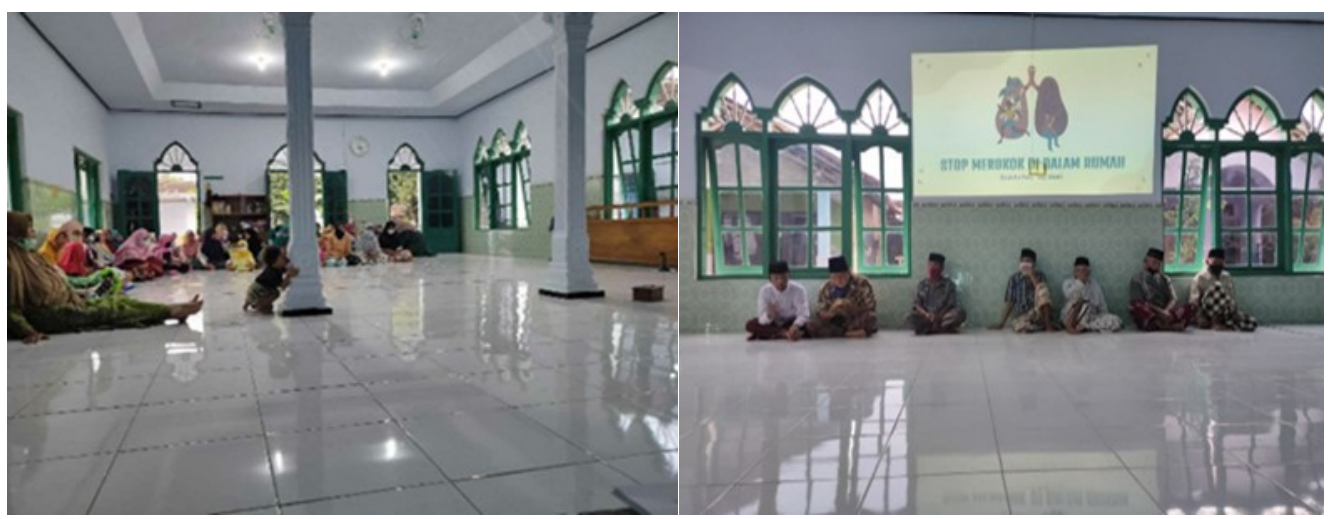

Gambar 2. Kegiatan penyuluhan

Setelah pemaparan materi edukasi dilakukan pengisian lembar evaluasi. Pengisian dilakukan oleh 25 orang. Terdapat beberapa masyarakat yang tidak bisa baca tulis, dan keterbatasan waktu dalam pengisian evaluasi menjadi kendala dalam kegiatan ini. Berdasarkan hasil analisis dari pengisian lembar evaluasi kegiatan penyuluhan "Stop Merokok di dalam Rumah", didapatkan hasil karakteristik responden perempuan sebesar 56\%. Distribusi asal dari responden RT 1 sebesar 28\%, RT 2 sebesar 36\% dan RT 3 sebesar 36\%.

Berdasarkan kemanfaatan edukasi didapatkan $88 \%$ responden menyatakan kegiatan penyuluhan ini sangat bermanfaat bagi masyarakat. Sebesar $60 \%$ responden menyatakan bahwa kegiatan penyuluhan ini mudah dimengerti, dan $76 \%$ responden menyatakan bahwa penyuluhan ini membuat responden sangat paham terkait pentingnya tidak merokok di dalam rumah. Sebesar $76 \%$ responden setuju untuk menciptakan rumah tanpa asap rokok dan $100 \%$ responden menyatakan bahwa penyuluhan ini dapat meningkatkan pengetahuan terhadap bahaya merokok di dalam rumah. Sebesar $64 \%$ responden belum pernah mengikuti penyuluhan terkait rokok.

Berdasarkan hasil evaluasi pelaksanaan kegiatan, masyarakat Dusun Krandon mengikuti kegiatan edukasi stop merokok didalam rumah dengan baik dan kegiatan dapat berjalan dengan lancar, programnya terstruktur, terdapat pemutaran video terkait bahaya merokok sehingga mempermudah pemahaman masyarakat. Masyarakat Dusun Krandon berharap untuk diadakan penyuluhan-penyuluhan yang lain agar masyarakat semakin sadar pentingnya kesehatan bagi tubuh. Masyarakat juga berharap dengan adanya kegiatan penyuluhan ini dapat menjadi perhatian bagi masyarakat sehingga masyarakat dapat menerapkan dalam kehidupan sehari-hari dan lebih peduli terhadap kesehatan diri sendiri maupun orang lain.

Berdasarkan hasil penelitian menunjukkan bahwa dengan diberikannya pendidikan kesehatan dapat mempengaruhi pengetahuan responden tentang bantuan hidup dasar pada kecelakaan lalu lintas[8]. Hal ini pun sesuai dengan pernyataan bahwa pengetahuan adalah hasil tau seseorang setelah melakukan pengindraan terhadap suatu objek [9]

Beberapa penelitian membuktikan bahwa penyuluhan berpengaruh terhadap pengetahuan. Penyuluhan akan mempengaruhi sikap individu. Sikap seseorang dapat berubah karena penyuluhan mempengaruhi pengetahuan seseorang. Materi dan media yang digunakan dalam penyuluhan mempengaruhi minat peserta. Materi yang menarik dengan disertai gambar, poster, dan video tentang testimoni penderita penyakit akibat merokok akan lebih meningkatkan perhatian dan minat peserta [10].

Penelitian yang dilakukan oleh Takaheghesang et al., (2019) menyatakan bahwa dengan diberikannya perlakuan berupa penyuluhan kesehatan dapat meningkatkan pengetahuan pada pelajar. Terdapat pengaruh dari penyuluhan kesehatan tentang bahaya merokok terhadap pengetahuan pelajar sekolah menengah atas di desa Likupang I Kabupaten Minahasa Utara dengan hasil yang bermakna pada kelompok kontrol dan eksperimen [11]. 
Waktu yang singkat untuk penyuluhan kesehatan hanya menghasilkan perubahan atau peningkatan pengetahuan yang belum dapat berpengaruh langsung terhadap indikator kesehatan tetapi akan berpengaruh kepada perilaku sebagai hasil jangka menengah dari promosi kesehatan, yang selanjutnya perilaku kesehatan akan berpengaruh pada peningkatan indikator kesehatan sebagai hasil dari promosi kesehatan itu sendiri, hal ini berbeda dengan program pengobatan yang hasilnya dapat langsung dilihat [9].

Disamping kegiatan penyuluhan, penulis juga melakukan pemasangan poster "Jadikan Rumah Bebas Asap Rokok!" di papan pengumuman masjid Baiturrahman Dusun Krandon dan TK Bustanul Athfal 'Aisyiyah Kwaren II guna meningkatkan perhatian dan himbauan kepada masyarakat untuk tidak merokok di dalam rumah. Jumlah poster yang dipasang adalah dua poster dengan ukuran A3. Melihat dari keadaan di lapangan, masyarakat sangat tertarik untuk melihat dan memperhatikan informasi yang disampaikan melalui poster tersebut.

Poster banyak diminati oleh sebagian orang karena gambar jelas dengan warna yang cerah, penggunaan kata dan kalimat yang singkat dan sederhana, serta bahasa yang digunakan mudah dipahami sehingga apa yang ingin disampaikan oleh pemateri dapat tersampaikan kepada pembacanya. Pemahaman yang lebih mendalam diperoleh jika poster tidak hanya menjadi pajangan begitu saja, tetapi harus diulang secara lisan baik dari petugas kesehatan, penyuluh, dan lain-lain [8]. Hasil penelitian pada siswa SD menunjukkan penggunaan poster dapat mempengaruhi pengetahuan siswa tentang kebersihan gigi [12]. Poster rumah bebas asap rokok yang diletakkan di tempat umum dapat sebagai pengingat bagi masyarakat agar tidak merokok di dalam rumah. Kegiatan ini sejalan dengan target pemerintah dalam rangka hari bebas tembakau sedunia yang mentargetkan lima juta masyarakat berhenti merokok [13].

\section{KESIMPULAN DAN SARAN}

Pelaksanaan kegiatan edukasi stom merokok didalam rumah di Dusun Krandon, Kwaren, Ngawen, Klaten dapat terlaksana dengan baik dan lancar. Penyuluhan stop merokok di dalam rumah dapat menambah wawasan dan kesadaran masyarakat tentang bahaya merokok di dalam rumah. Masyarakat sangat antusias dan aktif merespon pertanyaan penulis. Kegiatan ini merupakan salah satu upaya mengedukasi masyarakat tentang bahaya merokok dan menjadikan masyarakat berperilaku lebih baik dengan berhenti merokok. Kegiatan edukasi perlu ditingkatkan agar masyarakat lebih sehat.

\section{UCAPAN TERIMA KASIH}

Penulis mengucapkan terima kasih kepada Universitas Ahmad Dahlan yang memberikan dukungan sehingga kegiatan ini dapat berjalan dengan baik dan juga kepada masyarakat Dusun Krandon yang turut berperan aktif dalam pelaksanaan kegiatan pengabdian. Ucapan terima kasih juga kepada kepala RT 02 dan kader kesehatan Dusun Krandon yang telah membantu dalam pelaksanaan kegiatan.

\section{DAFTAR PUSTAKA}

[1] M. B. Boseke, S. Engkeng, and A. A. . Tucunan, "Determinan Perilaku Merokok Kepala Keluarga Di Kelurahan Woloan 1 Utara Kecamatan Tomohon Barat Kota Tomohon," Kesmas, vol. 8, no. 7, pp. 319-327, 2019.

[2] Kementrian Kesehatan RI, "Kemenkes Luncurkan Hasil Survei Tembakau,” 2012. https://www.kemkes.go.id/article/view/2048/kemenkes-luncurkan-hasil-surveitembakau.html.

[3] A. N. Sholeh, Panduan Anti Merokok untuk Pelajar, Guru, dan Orang Tua. Jakarta: Erlangga, 2017.

[4] Kementrian Kesehatan RI, “Laporan Riskesdas 2018," Lap. Nas. RIskesdas 2018, vol. 
53, no. 9, pp. 181-222, 2018, [Online]. Available:

http://www.yankes.kemkes.go.id/assets/downloads/PMK No. 57 Tahun 2013 tentang PTRM.pdf.

[5] ASH, Secondhand Smoke: the impact on children. 2017.

[6] S. Asma et al., The GATS Atlas Global Adult Tobacco Survey, vol. 112, no. 3. 2015.

[7] T. B. Indrajati, T. Istiarti, and A. Kusumawati, "Faktor-Faktor Yang Berhubungan Dengan Praktik Ibu Dalam Mencegah Paparan Asap Rokok Pada Balita Perokok Pasif," J. Kesehat. Masy., vol. 5, no. 5, pp. 1123-1131, 2017.

[8] Sumartono and H. Astuti, "Penggunaan poster sebagai media komunikasi kesehatan," Komunikologi, vol. 15, no. 1, pp. 8-14, 2018.

[9] S. Notoatmodjo, Kesehatan Masyarakat Ilmu dan Seni. Jakarta: Rineka Cipta, 2011.

[10] H. D. Anggraheny and A. Novitasari, "Upaya Mengatasi Perilaku Merokok dengan Penyuluhan Bahaya Merokok di Kelurahan Rejosari Semarang," Pros. Semin. Nas. Unismuh, vol. 2, pp. 143-147, 2019.

[11] H. A. Takaheghesang, S. Engkeng, and H. Adam, "Pengaruh Penyuluhan Kesehatan Tentang Bahaya Merokok Terhadap Pengetahuan Pelajar Sekolah Menengah Atas Di Desa Likupang 1 Kabupaten Minahasa Utara," Kesehat. Masy., vol. 8, no. 6, pp. $211-$ 217, 2019.

[12] R. Siregar and S. Sondang, "Efektifitas Penyuluhan Dengan Media Poster Terhadap Peningkatan Pengetahuan Tentang Kebersihan Gigi Pada Siswa/I Kelas III Dan IV Di Sdn 104186 Tanjung Selamat Kecamatan Sunggal Tahun 2014," J. Ilm. PANNMED (Pharmacist, Anal. Nurse, Nutr. Midwivery, Environ. Dent., vol. 9, no. 2, pp. 166-169, 2019, doi: 10.36911/pannmed.v9i2.315.

[13] Kementrian Kesehatan RI, "Peringati Hari Tanpa Tembakau Sedunia, Kemenkes Targetkan 5 Juta Masyarakat Berhenti Merokok," Biro Komunikasi dan Pelayanan Masyarakat, Kementerian Kesehatan RI, 2021.

https://www.kemkes.go.id/article/view/21060100002/peringati-hari-tanpa-tembakausedunia-kemenkes-targetkan-5-juta-masyarakat-berhenti-merokok.html (accessed Jul. 01, 2021). 